\title{
Analysis of $T$ cell subsets in the peripheral blood and synovial fluid of patients with rheumatoid arthritis by means of monoclonal antibodies
}

\author{
O. DUKE ${ }^{1}$ G.S.PANAYI ${ }^{1}$ G. JANOSSY $,{ }^{2} L . W . P O U L T E R,{ }^{2}$ AND N. TIDMAN ${ }^{2}$
}

From the 'Departments of Medicine and Rheumatology, Guy's Hospital Medical School, London SE1 9RT, and the ${ }^{2}$ Department of Immunology, Royal Free Hospital School of Medicine, London NW3 2QG

SUMmARY In an attempt to define the immunoregulatory mechanisms operating in rheumatoid arthritis we have enumerated $\mathrm{T}$ cell subsets in the peripheral blood and synovial fluid of patients with this disease. The peripheral blood analysis revealed an elevation of the ratio of inducer $\mathrm{T}$ cells (OKT4 positive) to suppressor/cytotoxic T cells (OKT5 positive) in patients with clinically active rheumatoid arthritis when compared with normal persons. This was due to a reduction in the percentage of suppressor/cytotoxic $T$ lymphocytes in these patients. The synovial fluid in rheumatoid arthritis differed from the peripheral blood in 2 respects. Firstly, synovial fluid was characterised by a lower helper: suppressor ratio due to an increased number of suppressor/cytotoxic cells, and, secondly, it contained an increased number of activated $\mathrm{T}$ cells bearing HLA DR antigens. The majority of these activated $T$ cells belonged to the helper/inducer $T$ cell subset.

Rheumatoid arthritis (RA) has many features which suggest it is an immunologically mediated disease, and consequently much effort has been directed towards trying to identify abnormalities in the blood lymphocyte population of patients with this disease. One approach has been to identify lymphocyte subpopulations by the use of specific cell surface markers and to see if any quantitative abnormalities exist. Such studies have failed to reveal any consistent abnormality in patients with RA. ${ }^{1}$ Monoclonal antibodies (McAbs) are now available which identify functionally distinct, thymus-derived ( $T$ cell) lymphocyte subsets termed the $T$ helper/inducer or $T$ suppressor/cytotoxic cells. The use of these McAbs allows a more precise analysis of the immunoregulatory mechanisms operating in disease states, and has been of value in analysing lymphocyte populations in viral infections, immunodeficiencies, and autoimmune diseases. ${ }^{2}$ The aims of this study were first to enumerate inducer and suppressor $T$ cell subsets in the periperhal blood (PB) and synovial fluid (SF) of patients with RA, and secondly to see if activated $T$ cells expressing HLA DR antigens were present in

Accepted for publication 12 July 1982.

Correspondence to Professor G. S. Panayi. these compartments. This type of analysis might be expected to provide further information on the nature of the immunological abnormalities operating in this complex disease.

\section{Materials and methods}

Patients. PB was obtained from 25 patients with definite or classical RA (age range 21-80 years) and 17 control patients (age range 24-73 years) with a variety of noninflammatory musculoskeletal disorders. Paired samples of PB and SF from a further 6 patients, and SF alone from 1 other patient, with RA were also studied. Total white cell counts and differential white cell counts were performed on all samples.

Cell separation. PB mononuclear cells were separated by centrifugation on Ficoll/Triosil. ${ }^{3}$ SF samples were diluted 1 in 4 with phosphate buffered

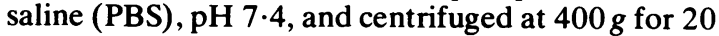
minutes. The cell pellet was resuspended in $10 \mathrm{ml}$ of PBS and mononuclear cells obtained by centrifugation on Ficoll/Triosil. Cell viability was checked by trypan blue exclusion.

The separated mononuclear cells were washed twice in PBS and adjusted to a concentration of 
Table 1 Reagents

\begin{tabular}{|c|c|c|c|}
\hline $\begin{array}{l}\text { First layer } \\
\text { reagents }\end{array}$ & Reactivity & $\begin{array}{l}\text { Species } \\
\text { origin }\end{array}$ & Reference \\
\hline \multicolumn{4}{|c|}{ A. Monoclonal antibodies } \\
\hline 1. OKT3 & $\begin{array}{l}\text { All peripheral } \\
\mathrm{T} \text { cells }\end{array}$ & & 4 \\
\hline 2. OKT4 & $\begin{array}{l}\text { Inducer } \mathrm{T} \text { cell } \\
\text { subset }\end{array}$ & Mouse & 5 \\
\hline 3. OKT5 & $\begin{array}{l}\text { Suppressor/ } \\
\text { cytotoxic T }\end{array}$ & & \\
\hline 4. OKT8 J & cell subset & & 6,7 \\
\hline \multicolumn{4}{|c|}{ B. Heterologous antibodies to } \\
\hline 1. HLA DR & $\begin{array}{l}\text { Human HLA DR } \\
\text { core antigen }\end{array}$ & Chicken & 8 \\
\hline $\begin{array}{l}\text { 2. Surface } \\
\text { membrane } \\
\text { immunoglobulin }\end{array}$ & B cells & Goat & \\
\hline
\end{tabular}

$2 \times 10^{7}$ cells $/ \mathrm{ml}$ in $\mathrm{PBS}+0 \cdot 2 \%$ sodium azide $+0 \cdot 2 \%$ bovine serum albumin (PBSA + alb). $50 \mu \mathrm{l}$ aliquots containing $1 \times 10^{6}$ cells were then placed in LP3 tubes (Luckham Ltd) for immunofluorescent staining.

Immunofluorescence. Standard direct and indirect double immunofluorescent tests were performed with the reagents shown in Table 1 . Briefly, an appropriate amount of the first layer antiserum was added to the cells and incubated at room temperature $\left(20^{\circ} \mathrm{C}\right)$ for 5 minutes. The cells were then washed twice in PBSA + alb and resuspended in $50 \mu l$. This procedure was repeated with the second layer reagents, and the cells were finally placed on a glass slide under a coverslip and sealed prior to examination for fluorescence on a Zeiss microscope equipped with an epifluorescence condenser IV/Z and selective filters for fluorescein isothiocyanate (FITC, green) and tetraethyl rhodamine isothiocyanate (TRITC, red).

The simultaneous analysis of cells with a McAb in combination with anti HLA DR was thus possible by using species-specific second layers labelled with FITC and TRITC respectively. This allowed identification of HLA DR-positive T cells. Similarly, by using subclass specific second layers appropriately labelled with FITC and TRITC the OKT4 and OKT5 antibodies could be used in combination to identify cells expressing both markers.

Counting and statistical analysis. Between 100 and 200 lymphocytes were counted, and the results were expressed both as the percentage of positive lymphocytes and as the absolute number of positive lymphocytes per $\mathrm{mm}^{3}$ of PB or SF. The results were analysed with the Mann-Whitney U test and Wilcoxon's signed rank test. RA patients were divided for statistical analysis into those with active and inactive disease according to the duration of morning stiffness, the
Table 2 Activity assessment score

\begin{tabular}{lllr}
\hline Score & $\begin{array}{l}\text { Early morning } \\
\text { stiffness (minutes) }\end{array}$ & $\begin{array}{l}\text { No. of } \\
\text { active joints }\end{array}$ & ESR $(\mathrm{mm} / \mathrm{h})$ \\
\hline 0 & $0-15$ & 0 & $0-24$ \\
1 & $16-45$ & $1-3$ & $25-49$ \\
2 & $46-89$ & $4-8$ & $50-74$ \\
3 & $>90$ & $>9$ & $>75$ \\
\hline
\end{tabular}

number of active joints, and the erythrocyte sedimentation rate (ESR) as shown in Table 2. Those patients scoring 6 or more points were classified as having active disease. Details of drug therapy were also taken.

\section{Results}

PERIPHERAL BLOOD ANALYSIS

$T$ cell subset analysis (Table 3 ). Patients with active RA were found to have an elevated T4:T5 ratio $(\mathrm{p}<0.01)$ in comparison with the normal group, which was due to a lower percentage of OKT5positive suppressor/cytotoxic cells $(p<0 \cdot 05)$. These patients also had lower absolute numbers of OKT5positive suppressor/cytotoxic cells than the normal or inactive RA group, though this did not reach statistical significance.

There were no differences between the normal and RA groups in the percentages and absolute numbers of either the OKT3-positive T cells or the OKT4positive helper/inducer $T$ cell subset, and only $1 \%$ or less of the lymphocytes in all samples showed double labelling with the OKT4 and OKT5 monoclonal antibodies.

Expression of HLA DR antigen (Ia-like) on T cell subsets (Table 4). A slightly increased percentage of HLA DR-bearing OKT3-positive cells was seen in patients with RA, but this was not statistically significant.

ANALYSIS OFPAIRED PERIPHERAL BLOOD AND SYNOVIAL FLUID SAMPLES

$T$ cell subset analysis (Table 5). The percentages and absolute numbers of OKT3-, OKT4-, and OKT8positive lymphocytes in the paired PB and SF samples were not significantly different in the 6 RA patients tested. There was, however, a trend towards increased numbers of OKT8-positive cells within the SF samples, which was responsible for a significantly decreased T4:T8 ratio in SF compared with PB (Fig. $1 \mathrm{p}<0 \cdot 05$, Wilcoxon signed rank test).

Expression of HLA DR antigen (Ia-like) on $T$ cell subsets. (Fig. 2). A marked increase in the percentages and absolute numbers of HLA DR-bearing OKT3-positive cells was seen in the SF compared 
Analysis of $T$ cell subsets in the peripheral blood and synovial fluid of patients

Table 3 Percentages and absolute numbers of PB lymphocytes reacting with OKT3, OKT4, and OKT5 antibodies

\begin{tabular}{|c|c|c|c|c|c|c|c|c|c|c|c|c|}
\hline \multirow[b]{3}{*}{ Patients } & \multicolumn{12}{|c|}{ Percentages } \\
\hline & \multicolumn{4}{|c|}{ Normal persons } & \multicolumn{4}{|c|}{ Inactive $R A$} & \multicolumn{4}{|c|}{ Active $R A$} \\
\hline & $T 3$ & $T 4$ & T5 & T4:T5 & $T 3$ & $T 4$ & T5 & $T 4: T 5$ & $T 3$ & $T 4$ & T5 & T4:T5 \\
\hline $\begin{array}{c}1 \\
2 \\
3 \\
4 \\
5 \\
6 \\
7 \\
8 \\
9 \\
10 \\
11 \\
12 \\
13 \\
14 \\
15 \\
16 \\
17 \\
\text { Median }\end{array}$ & $\begin{array}{l}80 \cdot 6 \\
68 \cdot 8 \\
46 \cdot 7 \\
55 \cdot 7 \\
68 \cdot 9 \\
73 \cdot 1 \\
71 \cdot 1 \\
59 \cdot 6 \\
61 \cdot 9 \\
67 \cdot 1 \\
77 \cdot 3 \\
56 \cdot 9 \\
65 \cdot 3 \\
61 \\
72 \\
62 \cdot 7 \\
73 \cdot 3 \\
67 \cdot 1\end{array}$ & $\begin{array}{l}53 \cdot 4 \\
48 \\
35 \cdot 7 \\
41 \cdot 7 \\
43 \cdot 4 \\
58 \cdot 8 \\
54 \cdot 7 \\
46 \cdot 1 \\
42 \cdot 8 \\
59 \cdot 5 \\
56 \cdot 4 \\
48 \cdot 6 \\
30 \cdot 7 \\
34 \cdot 2 \\
41 \cdot 3 \\
38 \cdot 8 \\
44 \cdot 3 \\
44 \cdot 3\end{array}$ & $\begin{array}{l}15 \cdot 8 \\
21 \\
13 \cdot 4 \\
22 \\
14 \\
18 \cdot 6 \\
14 \cdot 8 \\
14 \cdot 1 \\
13 \cdot 3 \\
14 \cdot 5 \\
27 \cdot 3 \\
17 \cdot 6 \\
18 \cdot 2 \\
22 \cdot 7 \\
34 \cdot 5 \\
24 \cdot 8 \\
33 \cdot 1 \\
18 \cdot 2\end{array}$ & $\begin{array}{l}3 \cdot 4 \\
2 \cdot 3 \\
2 \cdot 7 \\
1 \cdot 9 \\
3 \cdot 1 \\
3 \cdot 2 \\
3 \cdot 7 \\
3 \cdot 3 \\
3 \cdot 2 \\
4 \cdot 1 \\
2 \cdot 1 \\
2 \cdot 8 \\
1 \cdot 7 \\
1 \cdot 5 \\
1 \cdot 2 \\
1 \cdot 6 \\
1 \cdot 3 \\
2 \cdot 7\end{array}$ & $\begin{array}{l}60 \cdot 7 \\
44 \cdot 1 \\
62 \cdot 7 \\
74 \cdot 3 \\
64 \cdot 1 \\
46 \cdot 6 \\
63 \cdot 8 \\
65 \cdot 3 \\
60 \cdot 7 \\
69 \cdot 8 \\
62 \cdot 9 \\
62 \cdot 9 \\
70 \\
87 \cdot 1 \\
80\end{array}$ & $\begin{array}{l}41 \cdot 3 \\
37 \\
58 \\
35 \\
64 \\
20 \\
41 \cdot 5 \\
27 \cdot 5 \\
40 \cdot 4 \\
54 \cdot 6 \\
54 \cdot 8 \\
50 \\
51 \\
71 \cdot 2 \\
69 \cdot 5\end{array}$ & $\begin{array}{c}14 \cdot 3 \\
20 \\
44 \\
43 \\
7 \\
24 \\
9 \cdot 5 \\
31 \cdot 5 \\
23 \cdot 1 \\
16 \cdot 7 \\
20 \cdot 2 \\
15 \cdot 7 \\
17 \cdot 9 \\
11 \cdot 1 \\
27 \cdot 7\end{array}$ & $\begin{array}{l}2.9 \\
1.9 \\
1.3 \\
0.8 \\
9.1 \\
0.8 \\
4.4 \\
0.9 \\
1.8 \\
3.3 \\
2.7 \\
3.2 \\
2.9 \\
6.4 \\
2.5\end{array}$ & $\begin{array}{l}55 \cdot 9 \\
53 \\
61 \cdot 5 \\
52 \cdot 1 \\
84 \cdot 5 \\
66 \cdot 4 \\
67 \cdot 7 \\
40 \cdot 3 \\
61 \\
47 \cdot 4\end{array}$ & $\begin{array}{l}56 \\
35 \\
39 \cdot 8 \\
43 \\
67 \cdot 5 \\
60 \cdot 7 \\
39 \cdot 1 \\
34 \cdot 9 \\
44 \\
52 \cdot 6\end{array}$ & $\begin{array}{r}10 \\
7 \\
9.8 \\
14.4 \\
11.5 \\
16 \cdot 1 \\
21.9 \\
6.7 \\
26.6 \\
11.8\end{array}$ & $\begin{array}{l}5 \cdot 6 \\
5 \\
4 \cdot 1 \\
3 \\
5 \cdot 9 \\
3 \cdot 8 \\
1 \cdot 8 \\
5 \cdot 2 \\
1 \cdot 7 \\
4 \cdot 5\end{array}$ \\
\hline Median & \multicolumn{12}{|c|}{ Absolute numbers $/ \mathrm{mm}^{3}$} \\
\hline Median & 798 & 561 & 219 & & 987 & 662 & 251 & & 796 & 536 & 185 & \\
\hline
\end{tabular}

Significant differences between normal persons and RA patients are marked by asterix, "p<0.05 * $p<0.01$.

Table 4 Percentages of $O K T 3$ + cells expressing HLA DR antigen in $P B$ of normals and patients with $R A$

\begin{tabular}{|c|c|c|c|c|c|c|c|c|c|c|c|c|c|c|c|c|c|c|}
\hline Patient & 1 & 2 & 3 & 4 & 5 & 6 & 7 & 8 & 9 & 10 & 11 & 12 & 13 & 14 & 15 & 16 & 17 & Median \\
\hline $\begin{array}{l}\text { Normals } \\
\text { Inactive }\end{array}$ & 0 & 0 & 2.9 & 0 & 0.8 & 0 & 0 & $1 \cdot 7$ & 0 & 1.9 & 0 & 0 & 0 & 0 & 1 & 1 & 0 & 0 \\
\hline $\begin{array}{r}\text { RA } \\
\text { Active }\end{array}$ & 5.9 & 0 & 0 & 0 & 8 & $8 \cdot 8$ & 0.5 & 10 & 2 & 0 & 0.8 & 0 & 2 & 0.9 & & & & $0.8 \mathrm{NS}$ \\
\hline RA & 9 & 1.9 & 3.6 & 0 & 10 & 1.7 & $1 \cdot 5$ & 0 & 0 & 0 & & & & & & & & $1.6 \mathrm{NS}$ \\
\hline
\end{tabular}

NS =no significant difference.

Table 5 Percentages and absolute numbers oflymphocytes reacting with $O K T 3, O K T 4$, and $O K T 8$ antibodies in paired $P B$ and SF samples. The percentage and absolute numbers of T cells expressing $H L A D R$ antigens are also shown

\begin{tabular}{|c|c|c|c|c|c|c|c|c|}
\hline \multirow[t]{2}{*}{ Patients } & \multicolumn{8}{|c|}{ Percentages } \\
\hline & \multicolumn{2}{|l|}{$T 3$} & \multicolumn{2}{|l|}{$T 4$} & \multicolumn{2}{|l|}{$T 8$} & \multicolumn{2}{|c|}{$T 3^{+} / \mathrm{Ia}^{+}$} \\
\hline $\begin{array}{l}1 \\
2 \\
3 \\
4 \\
5 \\
6 \\
\text { Median }\end{array}$ & $\begin{array}{l}\text { SF } \\
86 \cdot 9 \\
87 \\
89 \cdot 9 \\
77 \cdot 8 \\
46 \\
77 \\
82 \cdot 35\end{array}$ & $\begin{array}{l}\text { PB } \\
92 \cdot 2 \\
69 \cdot 3 \\
80 \cdot 5 \\
74 \cdot 4 \\
80 \\
64 \cdot 4 \\
77 \cdot 2\end{array}$ & $\begin{array}{l}\text { SF } \\
38 \cdot 6 \\
49 \cdot 1 \\
59 \\
50 \cdot 5 \\
13 \cdot 3 \\
36.6 \\
43.85\end{array}$ & $\begin{array}{l}\text { PB } \\
59 \\
46 \cdot 5 \\
63 \\
58 \\
69 \cdot 5 \\
58 \cdot 4 \\
58 \cdot 7\end{array}$ & $\begin{array}{l}\text { SF } \\
49 \cdot 8 \\
41 \\
15 \cdot 7 \\
19 \cdot 6 \\
15 \cdot 2 \\
59 \cdot 6 \\
30 \cdot 3\end{array}$ & $\begin{array}{r}\text { PB } \\
37 \cdot 4 \\
15 \cdot 7 \\
8 \cdot 7 \\
19 \cdot 5 \\
27 \cdot 7 \\
6 \cdot 8 \\
17 \cdot 6\end{array}$ & $\begin{array}{l}\text { SF } \\
12 \cdot 2 \\
13.6 \\
13.7 \\
21.9 \\
30.4 \\
28.7 \\
17.8^{*}\end{array}$ & $\begin{array}{l}\text { PB } \\
2 \cdot 1 \\
0.9 \\
0 \\
0 \\
0 \\
1.9 \\
0.45^{*}\end{array}$ \\
\hline \multicolumn{9}{|c|}{ Absolute numbers $/ \mathrm{mm}^{3}$} \\
\hline Median & $2641 \cdot 5$ & $1188 \cdot 5$ & $1174 \cdot 5$ & $950 \cdot 5$ & 1154 & $224 \cdot 5$ & $410^{*}$ & $5^{*}$ \\
\hline
\end{tabular}

"Significant differences between PB and SF at $\mathrm{p}<0.05$. 


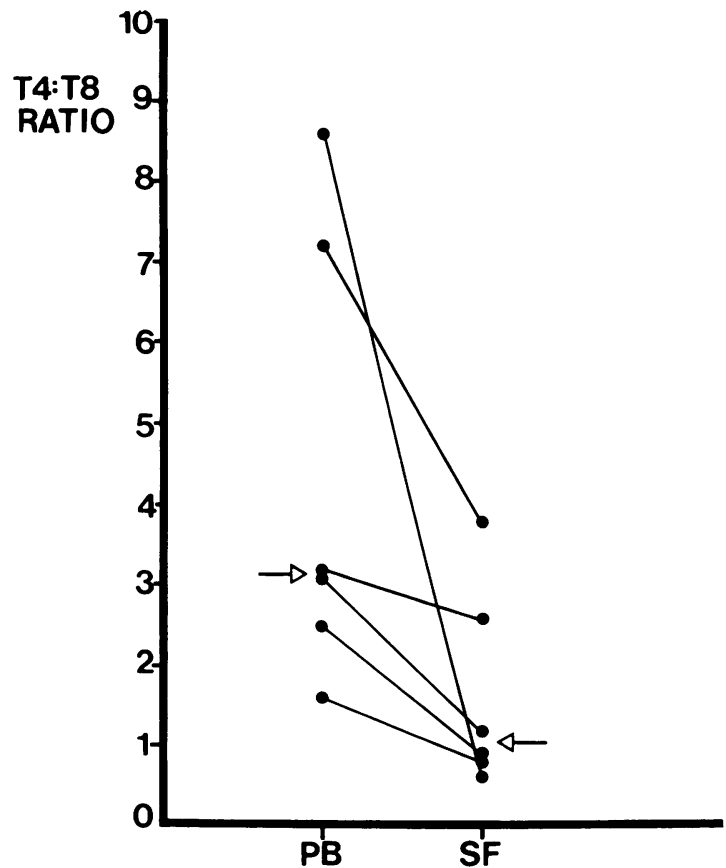

Fig. 1 The ratios of OKT4 +:OKT8 + lymphocytes in paired samples of peripheral blood $(P B)$ and synovial fluid (SF) from patients with $R A$. Median values (arrowed) are significantly different ( $p<0 \cdot 05$, Wilcoxon's signed rank test). $\bullet=$ Paired samples of peripheral blood and synovial fluid. $\circ=$ Single synovial fluid sample.

with matched PB samples (Table 5, p $<0.05$, Wilcoxon signed rank test). Further analysis revealed that these HLA DR-positive T cells in SF were contained in both the OKT4-positive, helper/inducer, and the OKT8-positive, suppressor/cytotoxic subset. There was no significant difference in the percentages of either OKT4-positive or OKT8-positive cells bearing HLA DR antigen, although in terms of absolute numbers there were significantly more HLA DR-positive cells of the helper/inducer phenotype per $\mathrm{mm}^{3}$ of SF. (Median values: HLA-DR ${ }^{+} / \mathrm{OKT}^{+}$, $152 \cdot 5 / \mathrm{mm}^{3}$, HLA-DR ${ }^{+} / \mathrm{OKT}^{+}, 30 \cdot 5 / \mathrm{mm}^{3}, \mathrm{p}<0 \cdot 01$ Mann-Whitney U test).

\section{Discussion}

This study has shown that patients with active RA have elevated T4:T5 ratios in PB resulting from a decrease in the proportion of cells expressing the OKT5 suppressor/cytotoxic phenotype. However, although the absolute number of circulating suppressor/cytotoxic cells was slightly reduced in this group when compared with normal persons, this was not statistically significant and is in contrast to the find-

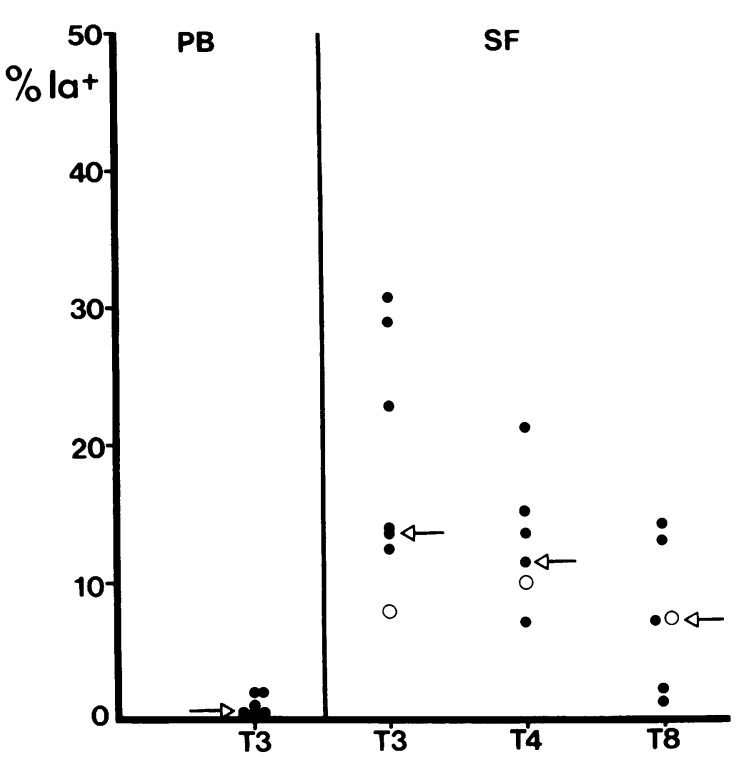

Fig. 2 The percentages of $O K T 3$ + cells bearing $H L A D R$ (Ia-like) antigens in paired samples of peripheral blood (PB) and synovial fluid (SF). Median values (arrowed) are significantly different ( $p<0.05$, Wilcoxon's signed rank test). The percentages of $O K T 4+$ and $O K T 8+$ cells bearing $H L A$ $D R$ antigen (Ia-like) in synovial fluid are also shown. Median values (arrowed) are not significantly different. $\bullet=$ Paired samples of peripheral blood and synovial fluid. $\circ=$ Single synovial fluid sample.

ings of other workers. ${ }^{9}{ }^{10}$ This discrepancy may result, firstly, from the selection of our patients, many of whom were taking drugs such as penicillamine, gold, chloroquine, and cortcosteroids, whereas in the studies previously mentioned patients had been on nonsteroidal anti-inflammatory medication alone. Secondly, the alteration in lymphocyte subsets may be observed to any significant extent only in those RA patients who have a lymphopenia as part of their disease. We reanalysed our results to answer these questions and found no differences in the $T$ cell subsets between RA patients on nonsteroidal antiinflammatory drugs, or second-line drugs, and normal persons. Only 4 of our patients $(2$ in the active and 2 in the inactive disease group) had a lymphopenia of $<1000 / \mathrm{mm}^{3}\left(1 \times 10^{9} / \mathrm{l}\right)$, and when analysed separately these patients showed significantly decreased absolute numbers of suppressor/cytotoxic lymphocytes compared both with normal persons and with those RA patients without a lymphopenia. If substantiated, this observation raises intriguing questions as to the nature and relevance of the lymphopenia and the associated fall in the number of suppressor/cytotoxic cells in the pathogenesis of RA. 
However, the minor changes in T cell subsets in PB are in sharp contrast to the relative lack of suppressor/cytotoxic cells within the RA synovial membrane (SM) that we have recently shown, ${ }^{11}$ and it seems that it is in the SM that abnormalities of suppressor cell function are likely to be of greatest importance. ${ }^{12}$

It is of interest that the T4:T8 ratio in SF is lower than the ratio in the corresponding sample of PB. This appears to be due to increased numbers of suppressor/cytotoxic cells within the SF, and in this respect SF seems to differ from the SM, where there appears to be a lack of these cells. The explanation of this anomaly may be that the cellular interactions which take place in SM result in OKT4-positive, helper/inducer cells being held up in the SM. These cells are found in clusters around strongly HLA DR-positive, interdigitating cells, while OKT8positive, suppressor/cytotoxic cells are scattered throughout the SM. ${ }^{11}$ This may also explain why enzyme digestion of SM in RA has been reported as showing more suppressor/cytotoxic cells than helper/inducer cells. ${ }^{13}$

Finally, the finding of increased numbers of HLA DR-positive T cells in SF compared with PB confirms the work of others. ${ }^{10}$ HLA DR antigen is a marker for immune activation in $\mathrm{T}$ cells ${ }^{14}$ and its presence on $\mathrm{T}$ cells in SF suggests that these cells are in an immunologically activated state. In addition we have found that the predominant $T$ cell subset expressing HLA DR antigens in SF is the OKT4-positive helper/inducer cell. This is in accord with our earlier report of HLA DR-positive T cells within the RA $\mathrm{SM}$, in which the predominant $\mathrm{T}$ cell subset was the OKT4-positive helper/inducer cell. ${ }^{11}$ However, the presence of HLA DR antigen on the cells of both the helper/inducer and suppressor/cytotoxic phenotype in SF requires explanation, and may be the result of activation either by a mitogen present within the SM or possibly by a specific antigen. Recent in-vitro work ${ }^{15}$ suggest the former mechanism is more likely and a possible candidate for the role of mitogen in the RA SM is interleukin 2, and further studies will be required to investigate this possibility.

This work was financed by a grant from the Arthritis and Rheumatism Council.

\section{References}

1 Froland S S, Abrahamsen T G. Lymphocyte populations in blood, synovial fluid and synovial tissue in rheumatoid arthritis. In: Panayi G S, Johnson P M, eds. Chertsey, Surrey: Reedbooks, 1979: 25-30.

2 Janossy G. The diagnostic and therapeutic uses of monoclonal antibodies. In: Hadden J, et al., eds. Oxford and New York: Pergamon Press, 1981.

3 Boyum A. Separation of leucocytes from blood and bone marrow. Scand J Lab Invest 1968; 21 (suppl 97): 77-89.

4 Kung P C, Goldstein G, Reinherz E L, Schlossman S F. Monoclonal antibodies defining distinctive human $\mathrm{T}$ cell surface antigens. Science 1979; 206: 347-9.

5 Reinherz E L, Kung P C, Goldstein G, Schlossman S F. Further characterisation of the human inducer $\mathrm{T}$ cell subset defined by monoclonal antibody. J Immunol 1979; 123: 2894-6.

6 Reinherz E L, Kung P C, Goldstein G, Schlossman S F. A monclonal antibody reactive with the human cytotoxic/suppressor $\mathrm{T}$ cell subset previously defined by a heteroantiserum termed $\mathrm{TH}_{2}$. J Immunol 1979; 124: 1301-7.

7 Kung P C, Talle M A, Demaria M, Butler M, Lifter J, Goldstein G. Strategies for generating monoclonal antibodies defining human T lymphocyte differentiation antigens. Transplant Proc 1980; 12 (suppl 2): 141-6.

8 Janossy G, Thomas J A, Bollum F J, et al. The human thymic microenvironment: an immunohistological study. J Immunol 1980; 125: 202-12.

9 Veys E M, Hermanns P, Goldstein G, Kung P, Schindler J, Van Wauwe J. Determination of $T$ lymphocyte subpopulation by monoclonal antibodies in rheumatoid arthritis influence of immunomodulating agents. Int $J$ immunopharmacol 1981; 3: 313-9.

10 Fox R I, Fong S, Sabharwal N, Carstens S A, Kung P C, Vaughan J H. Synovial fluid lymphocytes differ from peripheral blood lymphocytes in patients with rheumatoid arthritis. $J$ Immunol 1982; 128: 351-4.

11 Duke O, Panayi G S, Poulter L W, Janossy G. An immunohistological analysis of lymphocyte subpopulations and their micro-environment in the synovial membranes of paients with rheumatoid arthritis using monoclonal antibodies. Clin Exp Immunol 1982; 49: 22-30.

12 Janossy G, Panayi G S, Duke O, Bofill M, Poulter L W, Goldstein G. Rheumatoid arthritis: a disease of T lymphocyte/macrophage immunoregulation. Lancet 1981; ii: 839-42.

13 Burmester G R, Yu D T Y, Irani A, Kunkel H G, Winchester R J. $\mathrm{Ia}+\mathrm{T}$ cells in synovial fluid and tissues of patients with rheumatoid arthritis. Arthritis Rheum 1981; 24: 1370-6.

14 Winchester R J, Kunkel H G. The human Ia system. $A d v$ Immunol 1979; 28: 221-92.

15 Reinherz E L, Kung P C, Pesando J M, Ritz J, Goldstein G, Schlossman S F. Ia determinants on human T-cell subsets defined by monoclonal antibody: activation stimuli required for expression. J Exp Med 1979; 150: 1472-82. 